\title{
Status and socio-economic significance of wetland in the tropics: a study from Bangladesh
}

\begin{abstract}
Rana MP (1), Chowdhury MSH ${ }^{(2)}$, Sohel MSI ${ }^{(1)}$, Akhter $S^{(1)}$, Koike $M^{(2)}$
This study was carried out in the adjacent communities of the Hakaluki haor, the largest inland freshwater wetland of Bangladesh to explore their socio-economic status and haor-based livelihood dependency. Hakaluki haor is a poverty stricken region with $37 \%$ households falling into extreme poor group having monthly income of Tk 2000.00 only. More than half of the community view Hakaluki haor as the vital source of livelihoods. The surrounding community is dependent on the haor in varying degree $(15 \%$ totally dependent, $32 \%$ moderately and $53 \%$ less) with a variety of livelihood activities like fishing and related profession (32\%), duck rearing $(29 \%)$, cattle rearing $(28 \%)$, fuel wood collection (6\%), sand extraction (3\%) and reed collection (2\%). The average annual household incomes from fishing of naturally available fish, pisciculture and NTFPs collection are Tk 21701.35 , Tk 31524.83 and Tk 2704.80 , respectively. The haor serves as the source of fuel for cooking to a majority of the community (48\%). The respondents identified over-exploitation of fish resources, use of excessive pesticides and gradual increase of human settlement in and around the haor as the most threatened events. With the designation as Ecologically Critical Area (ECA) by the government, immediate attempts should be taken to ensure sustainable utilization of the haor resources. Development of integrated management plan with a provision of the participation of local stakeholders may become the possible way of conserving this wetland.
\end{abstract}

Keywords: Livelihood, Wetland, NTFPs, Hakaluki haor, Bangladesh, Asia

\section{Introduction}

The term "haor" denotes the bowl-shaped large tectonic depression that receives surface runoff water by rivers and canals, and consequently, becomes very extensive water body in the monsoon and dries up mostly in the post-monsoon periods (Alam \& Hossain 2004). In Bangladesh haors are found mainly in the north/eastern region covering the parts of greater Sylhet and Mymensingh. Hakaluki haor is the largest inland freshwater wetland ecosystem in Bangladesh and one of the

(1) Department of Forestry and Environmental Science, Shahjalal University of Science and Technology, Sylhet-3114, Bangladesh; (2) Forest Policy Laboratory, Department of Forest Science, Faculty of Agriculture, Shinshu University, 8304 Minamiminow-Mura, Nagano-Ken, 399-4598 Japan

(a) Md Parvez Rana (parvez_200207@yahoo.com)

Received: May 07, 2009 - Accepted: Jul 21, 2009

Citation: Rana MP, Chowdhury MSH, Sohel MSI, Akhter S, Koike M, 2009. Status and socio-economic significance of wetland in the tropics: a study from Bangladesh. iForest 2: 172-177 [online: 2009-10-15] URL: http:// www.sisef. it $/$ iforest $/$ show. php?id=512 largest in south Asia (CNRS 2002, Ahmed et al. 2008). It is composed of 6000 beels (small freshwater lakes) and covers up to 18000 ha of area during rainy season in the periods of mid-May to mid-July (DoE 1999). While the beels have several inlets, such as the rivers - the Juri, the Kantinala, and the Kuiachari - there is only one outlet, the Kushiyara River (Ahmed et al. 2008). Hakaluki haor is located in the north-eastern part of Bangladesh, between the districts of Sylhet and Moulvibazar. It supports a wide variety of agricultural and horticultural crops and fast growing introduced timber species (Khan et al. 2004). A significant number of medicinal plants are also found in the haor. This haor ecosystem supports at least 73 species of wetland vegetation, which is nearly half of the national total of 158 species of vegetation (Choudhury \& Faisal 2005). It is a critical habitat and breeding ground for fish and other aquatic species and considered one of the four major "mother fisheries" in Bangladesh (Karim 1993). More than 100 fish species are available in the haor, one third of which are listed as endangered (Ahmed et al. 2008, Choudhury \& Faisal 2005). The haor is also the home for globally significant waterfowl especially large number of' migratory duck species that pass the winter season there. There was an estimation of wintering population of ducks in 1960s at between 40000 to 60000 (CWBMP 2004). There are a number of varieties of mammals and reptiles including snakes, frogs, turtles, toads, tortoises, squirrel, and the gangetic dolphin inhabiting in and around the haor.

About 200000 people live around Hakaluki haor; all of them, more or less, are dependent on its resources for their livelihoods (Choudhury \& Faisal 2005). As the haor floods annually, settlements are clustered along its slightly raised fringes. Fisheries and agriculture are the two major livelihoods for local people living in and around Hakaluki haor (CNRS 2004). The haor once was with plenty of wildlife and aquatic resources and covered with swamp forest, which in the recent time has become a fast-degraded landscape facing increased pressure and threats (Ahmed et al. 2008). The forest resources (swamp and reed land plants) in the haor area have no proper conservation and management technique, for which those are declining gradually. Such rapid degradation of the wetland ecology is causing devastating consequences on the community people living in, around and downstream of the haor who for generations were dependent for their livelihoods upon vital functions, services and benefits provided by this wetland. On ground of such threats and rapid degradation of the resources and in recognition of the urgent need to protect its unique ecology and biodiversity, the Government of Bangladesh has declared Hakaluki haor as an "Ecologically Critical Area" (ECA) in 1999 under the provision of the Bangladesh Environment Conservation Act (CNRS 2002). The fact that Hakaluki haor has been designated as an Ecologically Critical Area (ECA) signifies its importance as a reservoir of disappearing natural resources (Ahmed et al. 2008).

Bangladesh is an excellent representative of tropical regions rich with huge biological diversity. The wetlands of Bangladesh's north-eastern region have great ecological, commercial and socio-economic importance. The dynamic interaction of terrestrial and aquatic systems makes these wetlands highly valuable environmentally. The wetlands are recognized as containing very rich components of biodiversity of local, regional and national significance (Nishat 1993). The forest resources (swamp and reed land plants) in the haor area have no proper conservation and management technique, for which those are declining gradually. Despite a growing awareness of the need for protecting the environment, degradation has occurred rapidly during the last three decades. As a result, country's ecology has been damaged, forests depleted, wetlands destroyed, and bio- 
diversity considerably degraded. Due to the excess pressure from overpopulation, the wetlands are also under serious threat with most of it being encroached upon by the local people. In recent years, as a direct consequence of agricultural expansion, many wetlands have been shrunk or disappeared. Such degradation has brought about a loss of biodiversity, reduction in fish habitat and loss of wetland-based flora that are a valuable source of a wide range of non-timber forest products (NTFPs). Despite of this widespread values and use of such freshwater wetland as Hakaluki haor, most of the studies on wetland in the country concentrated mainly on the Sundarban mangrove wetlands (e.g., Chowdhury 2001, Islam 2003, Chowdhury et al. 2004, Iftekhar \& Islam 2004, Islam \& Haque 2004, Islam \& Wahab 2005, Gopal \& Chauhan 2006, Hoq et al. 2006, Hoque et al. 2006, Hoq 2007, Iftekhar \& Saenger 2008). A very little study was conducted on Hakaluki haor, particularly economic significance of Hakaluki haor in terms of the dependency of local people on it remains largely unexplored. The present study is an initial attempt to realize the interactions among the people, wetland resources and economic activities and to assess inter-linkages between economic and ecological function of the haor system that is directly linked with local livelihoods. The study will serve as a source of baseline information for future researchers interested on similar wetlands in the country.

\section{Methodology}

\section{Study Site}

Hakaluki haor lies between latitudes $24^{\circ}$ $35^{\prime} \mathrm{N}$ to $24^{\circ} 45^{\prime} \mathrm{N}$ and longitudes $92^{\circ} 00^{\prime} \mathrm{E}$ to $92^{\circ} 08^{\prime} \mathrm{E}$. It is administrated under five upazilas (sub-district: administrative entity) of two districts: Fenchuganj and Golapganj upazilas of Sylhet district and Kulaura Borolekha and Juri upazilas of Maulvibazar district (CNRS 2002). There are 11 unions (a rural administrative unit consisting of a number of villages) under these five upazilas. The study was conducted at Chatla beel and

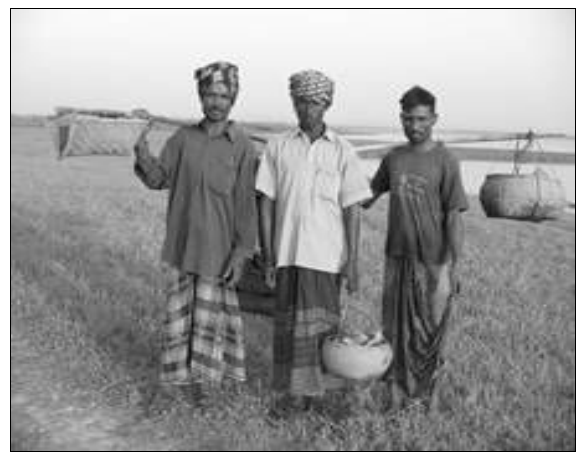

Fig. 2 - Fishermen in Hakaluki haor area.

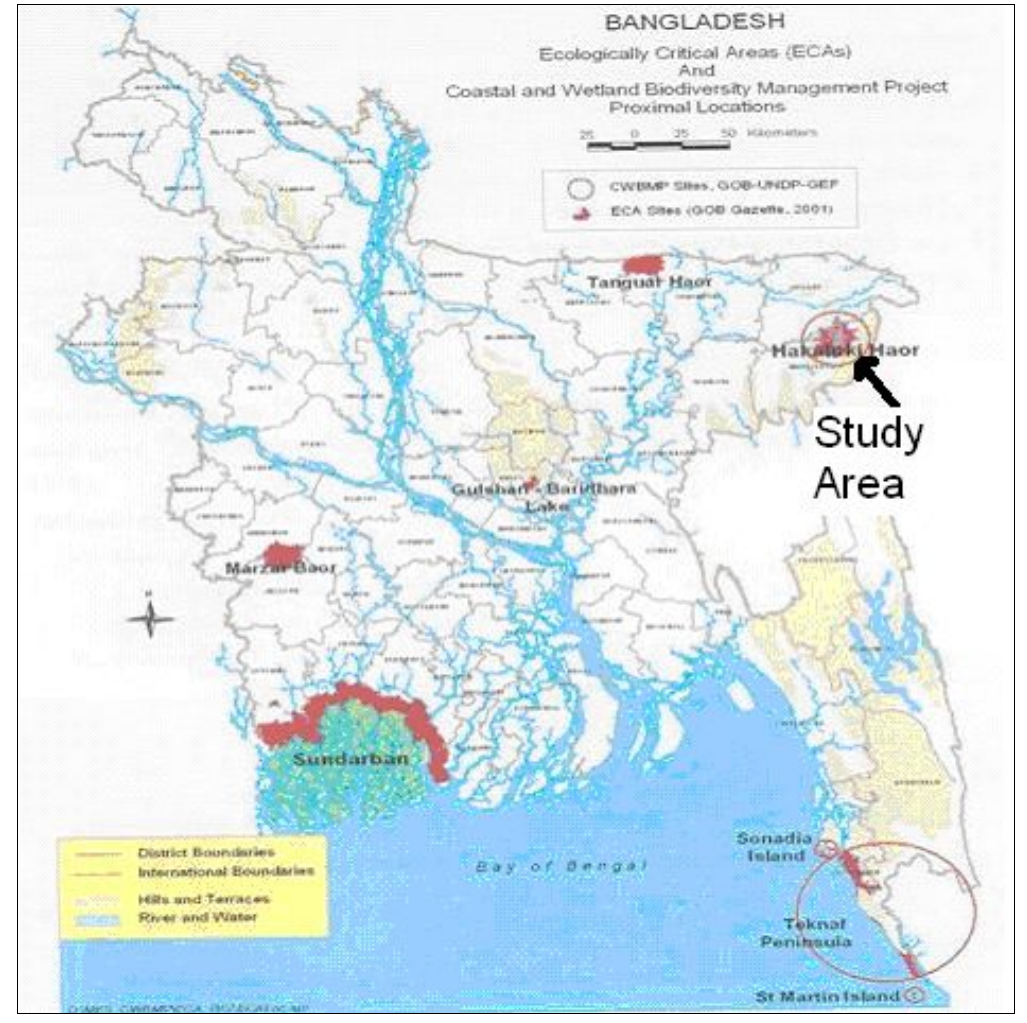

Fig. 1 - Major wetlands of Bangladesh showing the study area.

Jolla beel regions of Hakaluki haor situated under Jaifarnagor union of Kulaura upazila and Talimpur union of Borolekha Upazila, respectively (Fig. 1). Total area of Chatla beel is 302.9630 ha and adjacent villages are Sonapur, Velagaon, Bachirpur, Kandigaon, and Chalbon. The physical status of Chatla beel is moderately degraded. On the other hand, total area of Jolla beel is 181.3670 ha and adjacent villages are Sreerampur, Ranginagar, Mulajuri, Dasghori. The physical status of Jolla beel is moderately rich (CWBMP 2004).

\section{Methods}

The study was conducted in Borolekha and Kulaura upazilas of Moulvibazar district. A multi-stage random sampling technique was

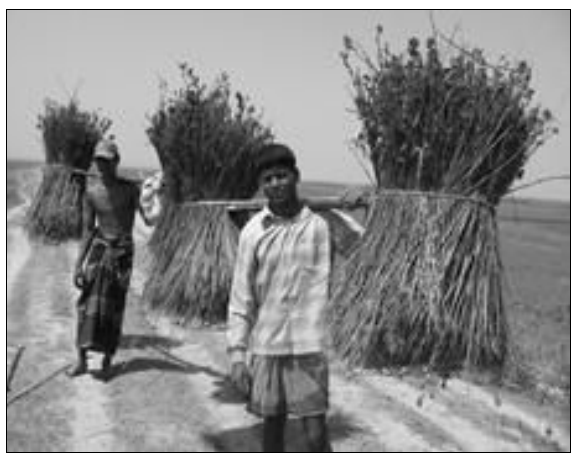

Fig. 3 - Fuel wood collection in Hakaluki haor area . applied for the study. From a total of 11 unions under the two upazilas, two unions (Jaifarnagar and Talimpur) were selected randomly. Two villages (Sonapur and Velagaon) from Jaifarnagar union, and two villages (Sreerampur and Mulajuri) from Talimpur union were selected using the same procedure. From these four villages 84 households with a sampling intensity of $12 \%$, were selected randomly for the survey. A semi-structured questionnaire was used for the interview which includes on various socio-economic parameters such as literacy, occupation, farm size, land ownership, knowledge sharing, organizational participation, involvement in farm activities, participation in decision making, access and rights on haor resources, livelihood patterns. Be-

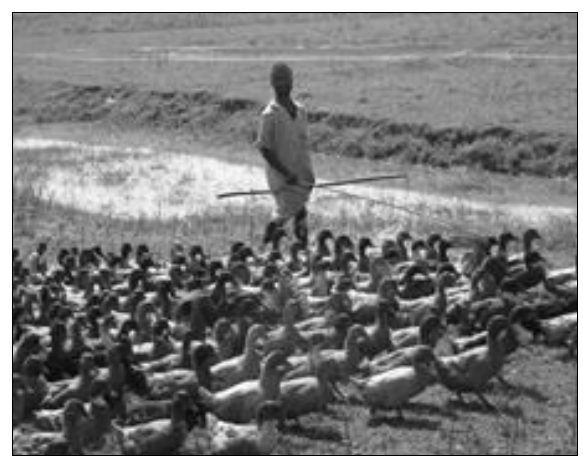

Fig. 4 - Duck rearing in Hakaluki haor area. 
Tab. 1 - Average annual household incomes from haor-based livelihoods.

\begin{tabular}{|c|c|c|c|c|c|c|}
\hline Resources & $\begin{array}{l}\text { Livelihood } \\
\text { activities }\end{array}$ & $\begin{array}{l}\text { No. of } \\
\text { respondents }\end{array}$ & $\begin{array}{l}\text { Frequency } \\
\quad(\%)\end{array}$ & $\begin{array}{c}\text { Average annual income } \\
\text { ( } \pm \text { Standard deviation) }\end{array}$ & $\begin{array}{l}\text { Total annual } \\
\text { income }\end{array}$ & $\begin{array}{c}\text { Overall } \\
\text { average } \\
\text { annual income }\end{array}$ \\
\hline \multirow{7}{*}{$\begin{array}{l}\text { Capturing } \\
\text { naturally available } \\
\text { fish }\end{array}$} & Full time fishing & 25 & 29.76 & $36911.76( \pm 4178.4)$ & 922794 & \multirow[t]{7}{*}{21701.35} \\
\hline & Part time fishing & 30 & 35.71 & $25066.67( \pm 3338.8)$ & 752000.1 & \\
\hline & Fishing for self consumption & 13 & 15.48 & $2807.73( \pm 909.3)$ & 36500.49 & \\
\hline & Fish drying & 8 & 9.52 & $666.67( \pm 249.8)$ & 5333.36 & \\
\hline & Weaving fishing net & 5 & 5.95 & - & - & \\
\hline & Others & 3 & 3.57 & $35428.57( \pm 4398.2)$ & 106285.7 & \\
\hline & Total & 84 & 100 & & 1822914 & \\
\hline \multirow{5}{*}{$\begin{array}{l}\text { Pisciculture in beels } \\
\text { and parts of haor }\end{array}$} & Supply of fries & 2 & 2.38 & $2250( \pm 537)$ & 4500 & \multirow[t]{5}{*}{31524.83} \\
\hline & Supply of fish feeds & 1 & 1.19 & 5000 & 5000 & \\
\hline & Fish trading & 27 & 32.14 & $26868.26( \pm 3222.1)$ & 725443.05 & \\
\hline & All the three categories above & 54 & 64.29 & $35428.57( \pm 4710.2)$ & 1913142.78 & \\
\hline & Total & 84 & 100 & - & 2648085.8 & \\
\hline \multirow[t]{9}{*}{ NTFPs } & Food for human & 14 & 16.67 & $3480( \pm 1180)$ & 48720 & \multirow[t]{9}{*}{2704.80} \\
\hline & Feed for cattle & 35 & 41.67 & $3430.78( \pm 1110.7)$ & 120077.30 & \\
\hline & Roofing materials & 2 & 2.38 & $1085.71( \pm 339.5)$ & 2171.42 & \\
\hline & Fencing materials & 6 & 7.14 & $888( \pm 310)$ & 5328 & \\
\hline & Fuel & 17 & 20.24 & $2620.89( \pm 889.5)$ & 44555.13 & \\
\hline & Medicinal plants & 1 & 1.19 & $3551.28( \pm 1000.5)$ & 3551.28 & \\
\hline & $\begin{array}{l}\text { Snail \& shell for poultry } \\
\text { farms }\end{array}$ & 2 & 2.38 & $1400( \pm 350)$ & 2800 & \\
\hline & Nothing & 7 & 8.33 & - & - & \\
\hline & Total & 84 & 100 & - & 227203.13 & \\
\hline
\end{tabular}

fore preparing the final questionnaire, a preliminary one was developed in conformity with the objectives of the study. This draft schedule was pre-tested with a few selected farmers. Some parts of the draft questionnaire were improved, rearranged, and modified in the light of the practical experience gained from the pre-test. It was then finalized and questions were listed in logical sequence, so that the respondents could answer easily. The selected respondents were personally interviewed for collecting reliable data and other information. The respondents were free to express their views on each of the topics. New avenues of questioning were pursued as the interview developed.

For the calculation of average annual household incomes from haor-based livelihoods (including NTFP's and medicinal plants), following formula was used: Net Income $=$ (revenue from sales of labour and goods, i.e., haor resources + the value of non purchased goods consumed, i.e., haor resources) - (material cash costs + opportunity costs of labour) (Ambrose-Oji 2003). The interview schedule was designed to collect information in local units. However, these were converted into national/international standard units later. To analysis the data obtained from the field level, we used the commercial software MS EXCEL.

\section{Results}

Habitat category and land use pattern in Hakaluki haor

Five categories of habitat were found to exist in the region of Hakaluki haor: beels, rivers or canals, fallow lands, lands for boro crops and lands for rabi crops. Beels were reported to be used for fishing, hunting birds, collection of aquatic plants for food, fodder, and fuel while the rivers or canals for fishing, boating, and transportation. Fallow lands were used for grazing, infrequent vegetation culture, collection of grass and fuel wood. Lands for boro crops, seen at the edges of the haor and within beels becoming dry in the winter, were reported to be used for rice cultivation. On the other hand, lands for rabi crops, found as elevated along the edges of the haor, were used for the cultivation of oil seeds and pulses of various species.

Basic socio-economic and demographic features of the respondents

The total number of the population of studied households was 517 with an average family size of six. Fifty one percent of them were male. All the respondents were male with an average age of 43 years. The primary occupation of the respondent households was dominated by agriculture (38\%), followed by fishing $(22 \%)$, day labour $(15 \%)$, boatmanship (10\%), small business $(9 \%)$ and remittance from abroad $(6 \%)$. Based on the average annual income information of the households, we categorized them into three different classes: extremely poor (annual income 24000 ); medium (annual income of Tk 24 000-90 000) and rich (annual income of $>$ Tk 90000 ). It was found that $37 \%$ of the households occupied in the extremely poor group, while $32 \%$ in medium and $31 \%$ in rich category.

\section{Haor-based livelihoods and income generation}

It was revealed that the local people had traditionally been using the haor for various livelihood purposes for centuries (Fig. 2, Fig. 3, Fig. 4). During the study when specific question was asked regarding household dependency on the haor, $15 \%$ of them reported the total dependence on Hakaluki haor for livelihoods, while the others were moderately (32\%) or less dependent (53\%). Among them the people in extreme poor category were found to be entirely dependent on the haor. On an average, the respondents were reported to be involved in a variety of haorbased livelihoods: fishing and related activities $(32 \%)$, duck rearing $(29 \%)$, cattle rearing (28\%), fuel wood collection (6\%), sand extraction $(3 \%)$, and reed collection $(2 \%)$. We 
Tab. 2 - List of NTFP's and medicinal plants available in Hakaluki haor.

\begin{tabular}{|c|c|c|}
\hline H aor products & Local name & Scientific name \\
\hline \multirow[t]{32}{*}{ NTFP's } & Alughas & Glinus lotoides \\
\hline & Bansupari & Caryola urens \\
\hline & Bishkatali & Polygonum barbatum \\
\hline & Bot & Ficus benghalensis \\
\hline & Brahmishak & Herpestis manniera \\
\hline & Bulkokra & Chaetocarpus casianocarpus \\
\hline & Chapali ghash & Chenopodium ambrosoides \\
\hline & Fulkuri & Ageratum conyzoidcs \\
\hline & Gab & Diospyros perigrina \\
\hline & Haicha & A Iternanthera sessilis \\
\hline & Hatisur & Heliotropium indicum \\
\hline & Helancha & Enhydra fluctuam \\
\hline & Hijol & Barringtonia aculangula \\
\hline & Jalibet & Calamus tennis \\
\hline & Jalibet & Calamus tennis \\
\hline & Jarul & Lagerstroemia speciosa \\
\hline & Kalojam & Syzygium cumini \\
\hline & Karanch & Pongamia pinnata \\
\hline & Khagra & Phragmites karka \\
\hline & Khudijam & Syzygium fruticosa \\
\hline & Kukra & Polygonum glabrum \\
\hline & Mander, Piltamander & Erythrina variegate \\
\hline & Minjiri & Cassia siamea \\
\hline & Monchata & Randia dwnclorum \\
\hline & Narical & Cocos nucifera \\
\hline & Panidumur & Trewia nudiflora \\
\hline & Panihijal & Salix teirasperma \\
\hline & Rendi, Rain tree & Samanea saman \\
\hline & Shapla & Nymphaea nouchali \\
\hline & Singra & Trapa maximowiczii \\
\hline & Sitalpati & Clynogyne dicholoma \\
\hline & Tilamander & Erythrina ovatifolia \\
\hline \multirow[t]{15}{*}{ Medicinal plants } & $\mathrm{Am}$ & Mangifera indica \\
\hline & Assamlata & Eupaiorium odoratum \\
\hline & Dhol kalmi & Ipomoeae ftstulosa \\
\hline & Durba & Cynodon dactylon \\
\hline & Dutura & Datura metel \\
\hline & Gab & Diospyros perigrina \\
\hline & Hijol & Barringtonia acutangula \\
\hline & Jambura & Citrus grandis \\
\hline & Jarul & Lagerstroemia speciosa \\
\hline & Kochuripana & Vichhornia pseudoraphis \\
\hline & Monkochu & Alocacia indica \\
\hline & Nishinda & Vitex negundo \\
\hline & Swarnalata & Cuscuta auslralis \\
\hline & Thankuni & Centella asiatica \\
\hline & Tulshi & Ocimum amcricanum \\
\hline
\end{tabular}

evaluated the incomes of the households from haor-based livelihoods in three different aspects: aquatic resources mainly fishing related activities that involve naturally available fish in haor, pisciculture involving in fish rearing in beels and/or parts of haor, and non-timber forest products (NTFPs) that include both the aquatic and non-aquatic re- sources (Tab. 1). The annual average incomes from those three categories of livelihoods were found $\mathrm{Tk} 21701.35$, Tk 31524.83 and Tk 2704.80 , respectively. Among the NTFPs, average annual income from medicinal plants was the highest $(\mathrm{Tk}$ 3 551.28). All the respondents were reported to use plant parts and cow-dung as fuel for cooking purposes: a majority (48\%) reported the haor and its surroundings as the source; others collected it from homesteads $(25 \%)$, homestead and market (18\%) and market only $(9 \%)$. They mainly collected parts from hijol (Barringtonia acutangula L.), koroch (Pongamia pinnata (L.) Merr.), barun (Crataeva nurvala Buch-Ham.) and gagra (Xanthium indicum Koenig.) as fuel for cooking. The fruits of two aquatic plant bhat (Calamus tenuis Roxb.) and shingra (Cynometra ramiflora L.) were reported to be collected by the children. List of NTFP's and medicinal plants available in Hakaluki haor is shown in Tab. 2.

Respondents' perception about the importance of haor conservation

When the respondents were invited to express their perceptions about the importance of haor conservation, all of them gave their opinion. For the majority of them $(59.33 \%)$ Hakaluki haor was the vital source of livelihoods, while to others it appeared as the source of food only (11.90\%), fisheries sanctuary $(9.52 \%)$, natural fertilizer provider through siltation (8.33\%) and so on (Fig. 5). Opinion on the threatened phenomena for Hakaluki haor was also sought from the respondents, in response to which they identified over-exploitation of fish resources $(21.5 \%)$ and gradual increase of human settlement in and around the haor $(18.6 \%)$ as the most threatened events. Some other incidences were reported by the respondents as detrimental for the existence of Hakaluki haor (Tab. 3).

\section{Discussion}

Wetlands provide a wide range of economic, social and ecological benefits (Dugan 1990, IWRB 1992, Khan et al. 2009). Wetlands are one of the most productive and resourceful areas, which provide food, nonfood aquatic resources and retain the ecological balance for the local residents as well as for the nation (Dugan 1990, IWRB 1992). From the perspective of a developing country, wetlands are an important source of commercial fishing, agriculture, seasonal livestock grazing, wood collection, and ecotourism. In Bangladesh, where inland water bodies constitute nearly $50 \%$ of total land area (Khan et al. 1994), wetlands are critical to economic development and environmental improvement. The major role of wetland are nutrient retention/removal, support for food chains, fisheries production, habitat for wildlife, recreation, natural heritage values, biomass production, water transport, biodiversity presentation and micro-climate stabilization (Dugan 1990, IWRB 1992, Khan et al. 2009). The wetland environment unites the inhabitants into a society, which has a definite shape, culture and livelihood pattern. Due to the availability of wide variety of 
Tab. 3 - Threatening phenomena and their impacts on Hakaluki haor.

\begin{tabular}{lc}
\hline \multicolumn{1}{c}{ Destructive activities } & $\begin{array}{c}\text { Level of } \\
\text { invasion (\%) }\end{array}$ \\
\hline Over-exploitation of fish from the haor & 21.5 \\
Use of pesticides in and around the haor & 8.86 \\
Dumping of chemical waste from the nearby industries & 4.89 \\
Use of current nets/cloth nets for catching fish/ fingerlings & 9.98 \\
Loss of habitat/food/shelter for animals & 5.1 \\
Catching birds for bush meat & 1.5 \\
Gradual increase in human settlement in adjacent areas & 18.6 \\
Over-exploitation of tree species & 3.6 \\
Conversion of wetland into agricultural land & 13.98 \\
Pollution of water by throwing garbage and sweepings & 5.6 \\
Unsustainable collection of fuel wood & 4.56 \\
Use of firearms for hunting & 1.6 \\
\hline
\end{tabular}

harvestable products, the people in and around the wetlands are traditionally self-reliant and have subsistence-oriented economy and livelihoods. Bangladesh has traditionally been rich in fish stocks. The inland fisheries system is estimated to contribute almost $73 \%$ of total production and supplies $80 \%$ of the country's animal protein requirements (Khan et al. 2009). Khan \& Islam 2005 found that an annual economic output value estimated for Hail haor, another large wetland of Moulvibazar district is US\$ 8 Million, the net present value of which over 15 years is US\$ 83 million. CWBMP Project Document (MoEF 2006) found that average income of the people living around the Hakaluki haor from capture fisheries is over Tk 16000 pe household, and that nearly half of the households are engaged in this profession. Moreover, pisciculture is also a growing industry in the area, providing an average income of Tk 31524.83 for participating households. IUCN (2006) revealed, $23.54 \%$ people's monthly income in Hakaluki haor area is more than Tk 7000.00 . The present study explored an interesting scenario of the role of wetlands on local livelihoods and its impacts on wetland ecology in Bangladesh Ahmed et al. (2008) reported that fisheries and agriculture are the two major livelihoods for local people living in and around the wet-

lands while other livelihood supports are provided by cattle grazing, NTFPs collection, duck rearing, and sand mining from there. All these livelihoods are available in Hakaluki haor region also. Despite all these support to human livelihoods, many parts of the world have experienced loss or degradation of wetlands on a huge scale because of agricultural use, urbanization, excessive exploitation by local population (Kabii 1996). Hakaluki haor is also facing similar kind of threats (Tab. 3) mainly due to over exploitation, which ultimately deteriorates the haor ecology. Due to continuous degradation of the haor ecology, the respondents of the haor give emphasis about the importance of conserving the Hakaloki haor (Fig. 5). So there is a clear inter-linkage between economic and ecological function of Hakaluki haor. Development of integrated management plan with a provision of the participation of local stakeholders may become the possible way of conserving this wetland ecology.

\section{Conclusion}

This study underscores the reality that Hakaluki haor also constitutes an important source of natural capital, which yields high economic and livelihood values to surrounding populations and the country as a whole.

Fig. 5 - People's perception about the importance of conserving Hakaluki haor.

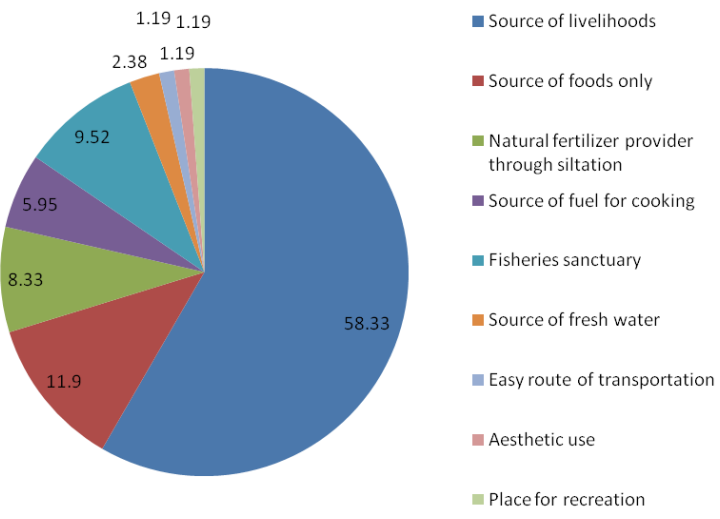

In Bangladesh the population is increasing day by day at higher rates but the natural resources are not increasing at the same time (Islam et al. 2005). Poverty greatly affects the environment and poverty is at a critical stage on the study area, which will influence the local people for continuous destruction of haor resources. Prevention of further decline of the wetland will require adoption of multiple-use land management based on principles of sustainable development. An integrated management plan is needed that includes utilization of wood and non-wood products, agriculture, fisheries and conservation of biodiversity. A core area and a buffer zone would need to be demarcated when allocating land use in wetland areas. Moreover, public awareness has to be developed for wetland resource management. It will also be necessary in some areas to relocate the encroachers and place restrictions on the entry of new settlers. Above all, sustainable management will only be possible if the government undertakes participatory management of wetland involving the stakeholders in and around the wetland areas.

\section{Acknowledgements}

Our sincere appreciation to all the respondents of the study area for sharing their information as well as for the heartiest cooperation during our field surveys. The authors deem their heartfelt gratitude to Mr. Md. Sharif Ahmed Mukul, Department of Forestry and Environmental Sciences, Shahjalal University of Sciences and Technology, Sylhet, Bangladesh for providing necessary literatures during manuscript preparation.

\section{References}

Ahmed I, Deaton BJ, Sarker R, Virani T (2008). Wetland ownership and management in a common property resource setting: A case study of Hakaluki Haor in Bangladesh. Ecological Economics 68 (1-2): 429-436. - doi: 10.1016/j.ecolecon.2008.04.016

Alam MS, Hossain MS (2004). Haor. In: "Banglapedia: the national encyclopedia of Bangladesh" (Islam S ed) Asiatic Society of Bangladesh, Dhaka, pp. 50-59.

Ambrose-Oji B (2003). The contribution of NTFPs to the livelihoods of the "forest poor": evidence from the tropical forest zone of south-west Cameroon. International Forestry Review 5 (2) 22-34. - doi: 10.1505/IFOR.5.2.106.17420

CNRS (2002). Bio-physical characteristics of Hakaluki Haor. Dhaka press, Bangladesh.

CNRS (2004). Bio-physical characteristics of Hakaluki Haor. Dhaka press, Bangladesh.

CWBMP (2004). Plant biodiversity (coastal and wetland biodiversity management project). Department of Environment, Government of the People's Republic of Bangladesh.

Choudhury JK, Faisal AM (2005). Plant Resources of Haors and Floodplains; An Overview, IUCN-The World Conservation Union. 
Bangladesh Country office, Dhaka, Bangladesh. Chowdhury MAK (2001). Changes in mangrove forest soils: a comparison between cultured and naturally inundated conditions. Wetlands Ecol Manag. 9 (2) 81-89. - doi: 10.1023/ A:1011159002862

Chowdhury Q, Rashid AZMM, Afrad M (2004) Socio-economic significance of reed forests in a rural community: a case study from the Greater Sylhet Region of Bangladesh. Small-scale Forest Economics, Management and Policy 3 (1): 121130 .

DoE (1999). Coastal and wetland biodiversity management project document. Department of Environment, Bangladesh. [online] URL: http:// www.doe-bd.org/cwbmp/pro doc/part i prodoc.pdf

Dugan PJ (1990). Wetland conservation: a review of current issues and required action. In: "Freshwater Wetlands in Bangladesh: Issues and Approaches for Management"(Nishat A, Hussain Z, Roy MK, Karim A eds). IUCN-The World Conservation Union, Switzerland, pp. 45-53.

Gopal B, Chauhan M (2006). Biodiversity and its conservation in the Sundarban mangrove ecosystem. Aquat. Sci. 68: 338-354. - doi: 10.1007/ s00027-006-0868-8

Hoq ME (2007). An analysis of fisheries exploitation and management practices in Sundarbans mangrove ecosystem, Bangladesh. Ocean \& Coastal Management 50 (5-6): 411-427. - doi: 10.1016/j.ocecoaman.2006.11.001

Hoq ME, Wahab MA, Islam MN (2006). Hydrographic status of Sundarbans mangrove, Bangladesh with special reference to post-larvae and juveniles fish and shrimp abundance. Wetlands Ecol. Manag. 14: 79-93. - doi: 10.1007/ s11273-005-2569-9

Hoque MA, Sarkar MSKA, Khan SAKU, Mora MAH, Khurram AKM (2006). Present status of salinity rise in Sundarbans area and its effect on Sundari (Heritiera fomes) species. Research Journal of Agriculture and Biological Sciences 2 (3): 115-121 [online] URL: http://www.insinet.net/rjabs/2006/115-121.pdf

IUCN (2006). Inception report: economic evaluation of Hakaluki Haor, Dhaka, Bangladesh. IWRB (1992). International Waterfowl and Wetlands Research. Action Programme for the Conservation of Wetlands in South and West Asia. In: "Freshwater wetlands in Bangladesh: issues and approaches for management" (Nishat A, Hussain Z, Roy MK, Karim A eds). IUCN- The World Conservation Union, Switzerland, pp. 112-119.

Iftekhar MS, Islam MR (2004). Managing mangroves in Bangladesh: a strategy analysis. Journal of Coastal Conservation 10: 139-146. - doi: 10.1652/1400-0350(2004)010[0139:MMIBAS] 2.0.CO;2

Iftekhar MS, Saenger P (2008). Vegetation dynamics in the Bangladesh Sundarbans mangroves: a review of forest inventories. Wetlands Ecology Management 16: 291-312. - doi: 10.1007/s11273-007-9063-5

Islam MA, Chowdhury NK, Haque MR (2005). Socio-Economic Baseline Survey of Pagnar and Sanuar - Dakuar Haors, Published by IUCN, Bangladesh.

Islam MS (2003). Perspectives of the coastal and marine fisheries of the Bay of Bengal, Bangladesh. Ocean \& Coastal Management 46: 763-796. - doi: 10.1016/S0964-5691(03)00064-4 Islam MS, Haque M (2004). The mangrove-based coastal and near shore fisheries of Bangladesh: ecology, exploitation and management. Reviews in Fish Biology and Fisheries 14(2):153-180. doi: 10.1007/s11160-004-3769-8

Islam MS, Wahab MA (2005). A review on the present status and management of mangrove wet- land habitat resources in Bangladesh with emphasis on mangrove fisheries and aquaculture. Hydrobiologia 54 (2): 165-190. - doi: 10.1007/s10750-004-0756-y

Kabii T (1996). An overview of African wetlands. In: "Wetlands, biodiversity and the Ramsar convention" (Hails AJ ed). Ramsar Convention Bureau, Switzerland, pp. 69-75.

Karim A (1993). Plant diversity and their conservation in freshwater wetlands. In: "Freshwater wetlands in Bangladesh: issues and approaches for management" (Nishat A, Hussain Z, Roy MK, Karim A eds). IUCN, Switzerland, pp. 75104.

Khan MI, Islam MA (2005). Poverty status of a critical wetland area: Hakaluki Haor. Published by IUCN, Dhaka, Bangladesh.

Khan MS, Haq E, Huq S, Rahman AA, Rashid SMA, Ahmed H (1994). Wetlands of Bangladesh. Holiday Printers Ltd., Bangladesh.

Khan MS, Haq E, Huq S, Rahman AA, Rashid SMA, Ahmed H (2004). Wetlands of Bangladesh. Bangladesh Centre for Advanced Studies in associated with Nature Conservation Movement.

Khan MS, Haq E, Huq S, Rahman AA, Rashid SMA, Ahmed H (2009). Wetlands of Bangladesh. Holiday Printers Ltd., Bangladesh. MoEF (2006). Coastal and wetland biodiversity management project document 2006. Ministry of Environment and Forests, Government of Bangladesh. Prepared \& Submitted by: IUCNBangladesh. In association with Center for natural resource studies.

Nishat A (1993). Freshwater wetlands in Bangladesh: Status and issues. In: "Freshwater wetlands in Bangladesh - issues and approaches for management" (Nishat A, Hussain Z, Roy MK, Karim A eds). IUCN, Switzerland, pp. 75104. 